\title{
Satirical expectations: Shakespeare's Inns of Court audiences
}

Jackie Watson

\section{(2) OpenEdition \\ Journals}

\section{Electronic version}

URL: http://journals.openedition.org/shakespeare/3352

DOI: 10.4000/shakespeare.3352

ISSN: 2271-6424

\section{Publisher}

Société Française Shakespeare

\section{Electronic reference}

Jackie Watson, "Satirical expectations: Shakespeare's Inns of Court audiences », Actes des congrès de la Société française Shakespeare [Online], 33 | 2015, Online since 10 October 2015, connection on 02 June 2020. URL : http://journals.openedition.org/shakespeare/3352 ; DOI : https://doi.org/10.4000/ shakespeare.3352

This text was automatically generated on 2 June 2020 .

(c) SFS 


\title{
Satirical expectations: Shakespeare's Inns of Court audiences
}

\author{
Jackie Watson
}

1 This article stems from a paper that was originally part of a Paris 450 panel entitled Shakespeare, Satire and "Inn Jokes". The other two contributors (Dr Derek Dunne and Dr Simon Smith) and I worked on the premise that theatre audiences in early modern London had a varied theatrical diet. Going from one playhouse to another in the 1590s, to experience the work of different playwrights and different playing companies, implied a series of different expectations. There can be overly sweeping binary suppositions about indoor and outdoor, so-called private and public, hall or amphitheatre playhouses. While avoiding generalizations that lead to sweeping comments on conventions, audiences and repertoire, and attempting a more nuanced approach, I propose to argue here for some commonality in the responses and expectations of a specific group of late Elizabethan playgoers.

2 Academics working on theatrical history and, specifically on individual playing companies, have demonstrated how generic developments can be traced through early modern theatre performance: developments to which elements of playgoing audiences often responded strongly. ${ }^{1}$ Within the audiences of most playhouses in the 1590 s was a collection of men who, although not a homogenous group, had several key factors in common. Men studying the law at London's four Inns of Court, and those at the related Inns of Chancery, were part of what George Buck termed "the third university". ${ }^{2}$ The men of the Inns are described by Jonson as "the Noblest Nurseries", and he applauds their nurturing of "Humanity and Liberty in the Kingdom" through their defence of the common law. ${ }^{3}$ Progression to the Inns was not, however, simply an exercise in legal learning. Philip J. Finkelpearl comments on their wider educational role as finishing schools and notes that, although "[i]t is difficult to ascertain exactly when such a use [...] arose", "it was essentially a product of Elizabeth's reign". ${ }^{4}$ Through their curricular and extra-curricular focus on verbal dexterity, their wider interests in dancing and 
playgoing, and their engagement with manners and skills suitable for social rising, the Inns enabled many young men with ambition to become key public figures in the late Elizabethan world. It is my argument here that an understanding of the common knowledge, training and experiences of Innsmen, and of the interests that many shared, enables us to deduce some likely responses of these men who formed a substantial group in many theatrical audiences.

3 Recent studies of early modern audiences have suggested two possible approaches. One of these, represented by Andrew Gurr and Charles Whitney, views the audience as a series of different "segments", each with its own characteristic interests and attitudes. ${ }^{5}$ In its extreme form, this could lead us to see each audience member individually, as undoubtedly every member of an audience - then, as today - does interpret a play slightly differently to his or her neighbour. The recent work of Jeremy Lopez reflects a second approach - reacting against the first - which characterizes the audience as an entity and responds to the tendency of early modern playwrights to address and refer to "the audience" as a more homogenous whole. ${ }^{6}$ While I am keen to avoid the reductio ad absurdum possible in the former approach, throughout this paper I take the line of Gurr and Whitney that certain elements of plays would have been of particular significance to men belonging to an Inns of Court segment of contemporary audiences, and that responses and understandings amongst that group would have some commonality.

4 To demonstrate this commonality, I address the intertextualities clustering around two comedies, connected both to each other and to the Inns of Court: Shakespeare's Twelfth Night and Marston's What You Will. After briefly establishing the generic context in which these comedies were written, my article explores the significance for this Inns of Court audience segment of Twelfth Night (subtitled, of course, What You Will). A final section then examines, within this context, possible connections between Shakespeare's and Marston's similarly titled plays.

Both plays, of course, were written in the final years of Elizabeth's reign, at a time when Shakespeare was predominantly writing for the adult company at the recently built Globe theatre, and Marston was providing scripts for the boy actors at St Paul's. Rosencrantz's famous speech in Hamlet comments on the rivalry between the adult and boy companies in this period:

there is, sir, an eyrie of children, little eyases, that cry out on the top of question and are most tyrannically clapp'd for't. These are now the fashion, and so berattle the common stages (so they call them) that many wearing rapiers are afraid of goosequills anddare scarce come thither. ${ }^{7}$

The suggestion here that "many wearing rapiers", courtiers and gentlemen, are forced by the satirical "berattl[ing of] the common stages" to avoid attendance at the Globe or other such "common stages" is unlikely. As Andrew Gurr argues, contemporary accounts of legal students' behaviour (including the affrays recorded between Innsmen and players) are suggestive that "Inns of Court students were regular playgoers from the start, and a conspicuous presence at the amphitheatres from early on". ${ }^{8}$ If we accept this, then the Innsmen who were part of the group "tyrannically" applauding in the private theatres attended plays at the amphitheatres too, particularly when plays were staged during the legal term. Then, rather than fleeing staged "goosequills" in fear, it may be argued that their generic preferences for the satire implied by Rosencrantz's image had an impact on the development of late Elizabethan repertoire. 
6 classical roots often seen as emerging from an Inns of Court culture valorizing verbal wit and combative rhetoric. ${ }^{9}$ The Bishops' Ban of 1599 presented a harsh public response to the fashion, forbidding the further printing of verse satire and epigrams, and also demanding the recall and burning of specific texts already printed. Clearly this verse genre, often produced by Innsmen and of which they formed a substantial readership, was seen as a challenge to the state. In his essay on the ideology behind the ban, William R. Jones argues that it "appears not as an attempt to eliminate all English satire, which had a well-established history, but rather to stem [...] a formally vituperative and ideologically iconoclastic mode executed in imitation of the Roman satirist Juvenal, a mode which appeared poised to overwhelm the more traditional, and sanctioned, modes of cultural critique". ${ }^{10}$ Marston, along with Innsmen colleagues Everard Guilpin, Tailboys Dymoke and John Davies, were named victims of the edict. ${ }^{11}$

7 This challenge to the satiric genre in verse and in print moved it into the playhouse and the War of the Theatres, or the Poetomachia, was a development of the scathing, morally indignant Juvenalian satire on stage. The two comedies under discussion here are thus contemporary with a conflict between playwrights during which Jonson created the term "satirical comedy" to define his 1599 play Every Man Out of his Humour. In his influential work on this period of theatrical history, James P. Bednarz argues that Jonson's creation of this label poses a challenge to the comic humour plays which had been in vogue during the 1590s and establishes his opposition to the "festive" or romantic style - a descriptor traditionally ascribed to the comedies of Shakespeare. ${ }^{12}$

the time/ Naked as at their birth" (15-16), Jonson declares his condemnatory satirical purpose, and reveals that he is shifting Juvenalian satire on to the stage. In the same manner as Marston's scourge of villainy, his "whip of steel" (17), fears nothing in declaring lawyers and courtiers to be "all corrupt" $(24) \cdot{ }^{13}$ His avowed lack of reverence for these groups of men is demonstrated by their being included in an early list of the play's targets alongside strumpets, ruffians and usurers. The Grex, the invited crowd represented on stage by Cordatus and Mitis, are requested by the metatheatrical Asper "as censors to sit here,/ Observe what I present, and liberally/ Speak your opinions upon every scene" (152-154). In this way, they model the behaviour Jonson demands of his audience members - and above all, they model what he should expect of the discerning audience segment from the Inns. Observers and judges abound as Jonson sets up level after level of spectatorship: the gulls observe each other closely; Carlo, observing them, acts as a Jonsonian "scourge" (2.2.157); Asper observes everyone metatheatrically, in his adopted role as Macilente; the Grex observe him; and the audience, guided by the Grex, observe them all. Jonson sets up a contract with his audience to make their own individual judgements quietly while deferring to the playwright, and, again, this contract is modelled by Mitis and Cordatus. Jonson's audience is that of the Globe, not an indoor playhouse. Yet the representation on stage of behaviour typically associated with those watching at Paul's or Blackfriars implies that the playwright's aim is to train members of his wider, public audience how to judge as an Innsmen might have been trained to judge: in the manner of a group of men, that is, with whom Jonson was very familiar. To scourge the behaviour of the gulls or fools we see paraded before us is to act as Marston in his verse satires or as epigrammatists from the Inns, such as Davies or Guilpin. In other words, to be an 
audience member at Jonson's Every Man Out is akin to reading the texts banned by Whitgift and Bancroft.

Generally taken to be typical of the romantic comedy genre, Twelfth Night is clearly very different in style to Jonson's experiments in satirical comedy and to Innsmen verse satire. Indeed, it might be argued that Jonson's and Shakespeare's plays challenge traditional expectations of the relationship between indoor and outdoor playhouses and their respective audiences. We might expect Every Man Out, for a public playhouse, to demand less of a judicial response from its audience, and Twelfth Night, with Middle Temple as one of its first audiences, to demand more. We might expect satire to feature more explicitly in plays written for Innsmen - yet it is Jonson's play which describes itself as "satirical comedy". Twelfth Night does not demand the same kind of audience response as Every Man Out, though it is also a play often preoccupied with observation, judgement and mockery of others. It is a particularly interesting play here as it is one of the few with a clear link to one of the Inns, and, indeed, one of the very few with a recorded response from one of its earliest audience members. That response, found in John Manningham's Diary, is to its performance on Candlemas, $2^{\text {nd }}$ February 1602, in Middle Temple Hall and it allows us to see how a contemporary Innsman interpreted the play. Although Manningham's response is not necessarily that of all his fellow law students, the elements of the play on which he focuses are perhaps indicative of interests and knowledge these young men held in common.

10 A closer examination of Manningham's reaction thus could give an insight into the relationship between Twelfth Night and one of its first audiences. In his response, the young law student first notes the similarity of the play to Latin and Italian sources, as well as to The Comedy of Errors (itself staged at Gray's Inn in 1594). In this he demonstrates the familiarity of many in this particular audience segment with a wide range of dramatic material - both on stage and in printed form. He goes on, though, to focus on one plotline within the play, suggesting that Malvolio and his treatment were of especial interest to him, as there is reason to believe they would be to many men in his position. There was, he writes:

A good practise in it to make the Steward believe his Lady widdowe was in love with him, by counterfeiting a letter as from his Lady in generall termes, telling him what shee liked best in him, and prescribing his gesture in smiling, his apparaile, \&c., and then when he came to practise, making him believe they tooke him to be mad. ${ }^{14}$

Manningham's focus on Malvolio is indicative of a fascination with sartorial experimentation, and an accompanying fear of making an error. The proximity between fears of young Innsmen and what happens to Malvolio can be see more clearly if we compare the play to the Middle Temple revels of 1597/8, Le Prince D'Amour performed just five years before the staging of Twelfth Night, in the same hall and attended by many of the same audience members. Both performances illustrate the potential peril of making the wrong choices of dress. In the homosocial, combative context of an Inn or a court of law, as in the playhouse, it is obvious that one's verbal performance could secure the victory of audience approval or result in the loss of it. Yet errors could be visual as well as verbal; selecting the wrong costume could also condemn a man to be vanquished through audience ridicule.

11 Benjamin Rudyerd's account of the period leading up to the revels reveals in a highly entertaining manner how the Prince's court took shape. These preliminary events 
expose a great deal about the dramatis personae. Key amongst this group is one of the satirists and epigrammatists condemned by the Bishops' ban - John Davies or, as he is often nicknamed in the text, Stradilax. His behaviour illustrates well for our purposes an exaggerated version of the performative skills encouraged at the Inns. His appearance on the Christmas Eve of the revels period, for instance, "in a MarmeladColour-Taffata Gown" suggests a man with the desire to attract attention. ${ }^{15}$ Perhaps, since we are told it "was never seen after", the response to his flamboyance led him to believe it ill judged. This misjudgement of dress, or perhaps others it symbolizes, resounds in the trick played on Malvolio.

The students of the Inns were major consumers of the popular courtier manuals which guided aspirant young men on important aspects of appearance and behaviour, including their dress. ${ }^{16}$ This can be seen, for example, in Galateo, a contemporary advice manual avowedly aimed at "gentlemen and other[s]", where the writer, Giovanni Della Casa, explains how "other[s]" can appear to be gentlemen. ${ }^{17} \mathrm{He}$ instructs his reader that "Your apparell must be shaped according to the fashion of the time, and your calling for the causes I have showed you before. For we must not take vpon vs to alter customes at our will... Euery man may applie those fashions, that be in common vse, the moste to his owne aduantage, that he can". He continues by warning men against wearing items which might be seen as "Ganymedes hosen" or "Cupides doublet", and thus cause ridicule. ${ }^{18}$ Reversing this sensible guidance, Maria's letter advises the unfortunate steward to perform a role unlike his usual one, smiling and wearing yellow stockings, cross-gartered. As a result, he meets a comparable ridicule to that experienced by Stradilax. In order to explain Malvolio's readiness to accept advice on his appearance, Shakespeare makes sure the audience of Twelfth Night see how the character grasps the importance of performance and appearance. These will, he knows, be vital if he is to succeed in his social aspirations. In the lines preceding his finding of Maria's letter in the orchard, he is observed to be "practising behaviour to his own shadow this half-hour" (2.5.16). As the three tricksters watch (rather in the manner of a giggling Grex) he enacts how he plans to respond when his "kinsman Toby" is called for: "I frown the while, and perchance wind up my watch, or play with my - some rich jewel. Toby approaches... I extend my hand to him thus, quenching my familiar smile with an austere regard of control" (2.5.57-65). This rehearsal of his future behaviour, when he will "have greatness thrust upon" him, will be key to his imagined success, and causes his ready agreement to "be strange, stout, in yellow stockings, and crossgartered" (2.5.165-166). For members of Shakespeare's Middle Temple audience, also socially aspirant, this could be taken as a warning not to transgress accepted sartorial norms when dressing to impress. ${ }^{19}$ It is clear why for John Manningham, and probably for many of his peers, this scene was a key one.

The banning of poetic satire and epigram in 1599 (naming the work of Middle Templars Marston and Davies) as well as the transfer of the satirical to the stage and Marston's key role in the Poetomachia, encourage us to think of the Middle Temple as holding a central position in the development of late Elizabethan satire. The friendship between Jonson and influential Middle Templars such as John Hoskins and Richard Martin provide further connections between members of the Inn and the period's skirmishes of wit. Indeed it is to Martin that Jonson dedicated the 1616 Folio edition of Poetaster with thanks for his earlier defence of the poet. This involvement of key Innsmen in the drama of the day adds weight to an argument that sees a play chosen to form the 
climax of the student-led 1601/1602 Christmas revels as engaged in the concerns of contemporary Innsmen. In his essay on the relationship between Twelfth Night, Every Man Out and the Prince D'Amour revels, Henk Gras sees Shakespeare's play being written with a Middle Temple audience in mind. This may mean that its first performance was at the Inn: a line argued as far back as 1930 by the then editor of the play, John Dover Wilson, and proposed again more recently by a current Middle Templar, Anthony Arlidge. ${ }^{20}$ However, it does not necessarily mean that. Early modern playwrights had, of necessity, to cater for a wide range of playgoers, and Gras points out that writing with such an audience in mind simply "mean[s] that for that selective audience the play could have had a different level of meaning from the one it would have had for the groundlings in the Globe or the nobility at court". ${ }^{21}$ It is possible to suggest, though, that the Sir Toby and Malvolio plot would hold a specific interest for this particular audience segment, and that his peers might echo Manningham's interests, as the play engages with issues of social mobility, appearance and respectability.

The closeness of its transgressions to those of the Middle Temple revels makes Twelfth Night highly suitable for performance at the Inn. It represents the tension between conformity to the signifiers of social acceptability and the challenge to them which is possible for those who stand outside them, perceive them and reflect upon their authority. Indeed, the very externality of the Middle Temple, situated geographically neither in the city nor in the court but somewhere between, can be seen as symbolic of the social situation of many of the Inn's residents.

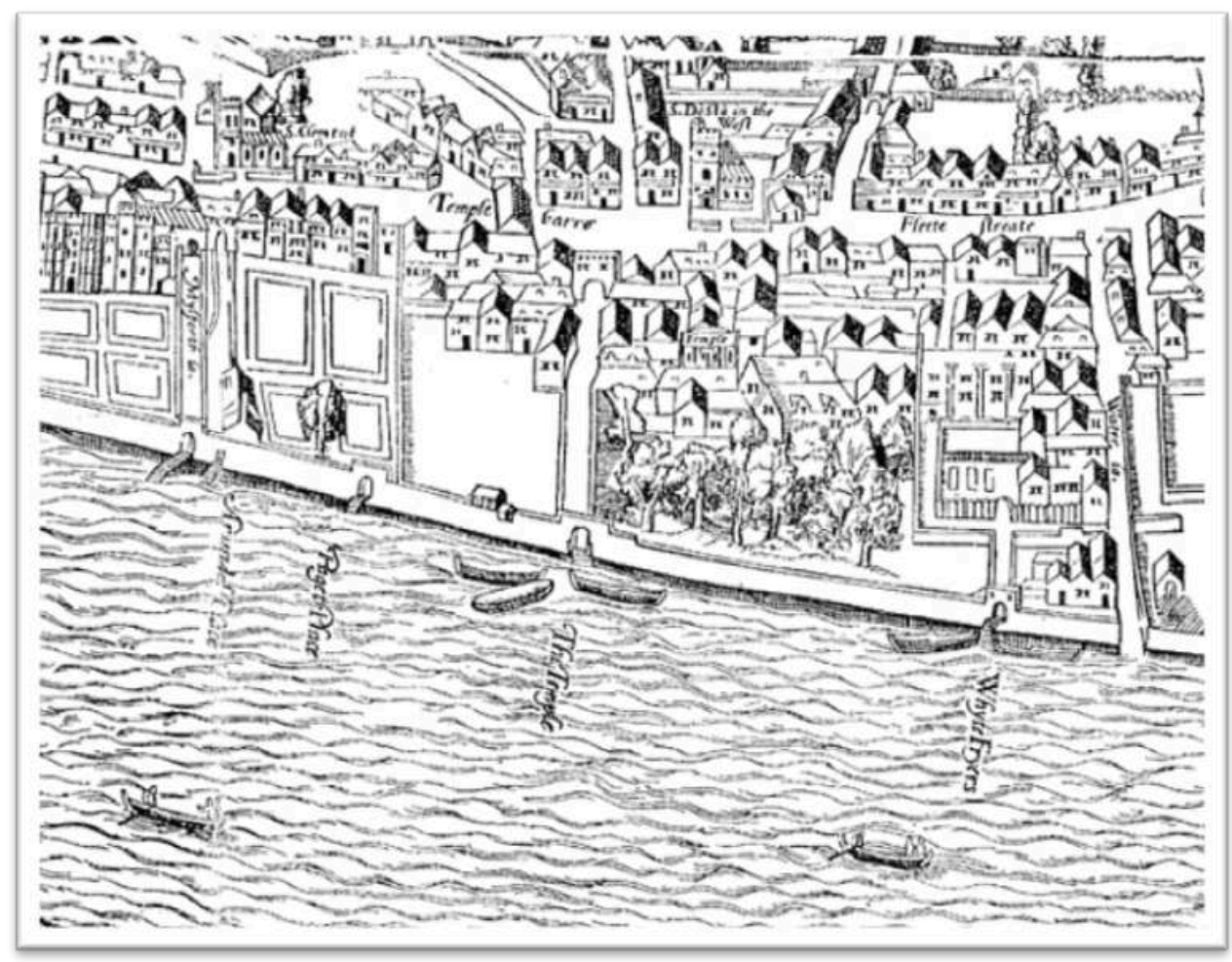

A section of the map of London by Ralph Agas (1576)

SHOWINg THE SITUATION OF MIDDLE TEMPLE TO THE WEST OF THE CITY, BESIDE WHAT ARE, A LITTLE LATER, TO BECOME WHITEFRIARS AND (JUST OFF THE MAP TO THE EAST) BLACKFRIARS THEATRES. LONDON METROPOLITAN ARCHIVE, REPRODUCED WITH PERMISSION. 
15 Just as Shakespeare's play stages the movement from the liminal shore where Viola emerges from the sea to the commonwealth of Orsino's and Olivia's establishments, many Innsmen desired to move from the social ambiguity of studentship to the court. Yet that ambition was difficult to achieve, requiring as it did daily rehearsal of the necessary performative skills and necessitating a conformity which many Middle Templars found unpalatable. The Inn, with the Hall at its heart, was a safe retreat from both the city and the court, as well as a seat from which to observe and judge them.

As a writer who had been observing and judging from his Middle Temple vantage point for some years, writing popular Juvenalian verse satires before the 1599 ban, the young John Marston's potential for combative wit and vituperative poetry was clear. His move to the stage is usually seen as a natural development and What You Will as a continuation of his instinct for satire. As one commentator notes, "Whatever its role in the War of the Theaters, Marston's achievement in What You Will was to dramatize the world of his verse satires without recourse to an intrusive representation of his own point of view". ${ }^{22}$ His depiction of the world of learning and its uncomfortable relationship to the aspirational society in which he lived allowed Marston to engage with the concerns and fears of his contemporary Innsmen as I have argued that, in a different dramatic form, Shakespeare did in Twelfth Night.

There are clearly textual echoes of one play in the other. A first performance at Middle Temple in 1602 would put Twelfth Night shortly after What You Will, usually dated to 1601, though most editors of the Shakespeare text suggest a series of possible first performance dates between January 1601 and February 1602. ${ }^{23}$ Whether Marston echoed Shakespeare, or the other way round, it is difficult to hear lines in the Marston without thinking of the better-known Shakespeare. Jacomo's reaction to the song early in What You Will is a good example, as he stops it with the line, "Fie, peace, peace, peace, it hath no passion in't", clearly reminiscent of Orsino's similar plea for the music to cease, "Enough, no more,/ "Tis not so sweet now as it was before" (1.1.7-8). ${ }^{24}$ Where Orsino's comment is on the music's "dying fall" (1.1.4), for Jacomo, "every note may seem to trickle down/ Like sad distilling tears" (245-246). Jacomo's desire for the love of a supposed widow is evocative of Orsino's for an Olivia mourning the death of her brother. This in itself is interesting. Shakespeare changes the widow in Barnaby Rich's short story 'Of Apolonius and Silla' to a mourning sister but Manningham writes of Olivia as a widow, either because he knows the source, or because he makes a wrong assumption based on the visual evidence of her mourning weeds alone. Equally, Marston's Celia is only an apparent widow - as her husband, we discover, is actually alive.

It is dangerous to draw too much from the many small connections of this kind, as What You Will also echoes the near-contemporary Hamlet in several places and quotes other popular plays such as Richard III. ${ }^{25}$ Part of Marston's appeal for the Innsmen he knew so well lay in his use of intertextual allusions that enabled the playgoing young men to display their familiarity with works they had seen or read. Equally, Marston shows a famous playfulness with language - using innuendo, allusion, flyting and rhetorical point-scoring - with a clear appeal to the verbally-astute Innsmen who were an influential segment within his audience. Marston's word coinage and use of inkhorn terms might have become a means of mockery and retaliation for Jonson in the Poetomachia, but they had direct appeal for those training in rhetorical flamboyance to gain attention in moots. In its attack on the satirist, Lampatho Doria, the play questions 
the mean-spirited bitterness of which the genre is capable, and rather disingenuously appears to advocate less Juvenalian modes. The terms in which this argument is developed appear designed to appeal to the highly literate Innsman playgoer:

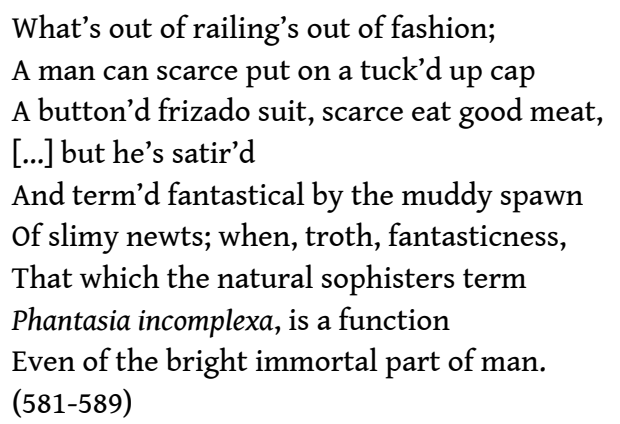

In his defence of his linguistic extravagance, combined with his attack on the railing of Lampatho, Marston is clearly waging another battle in the War of the Theatres - both defending himself against Jonson's attacks on him, and, in turn, attacking Jonson. The means by which he does this are likely to delight the Innsmen of his audience.

However, as well as the style Marston employs to appeal to his fellow Innsmen, most important to the argument of this essay is that Marston embodied in What You Will issues that engaged that segment of his audience, just as Shakespeare did in Twelfth Night: issues such as the importance of education, the connection between theatre and 'real' life, and the status of women. The Middle Templar's comedy asks its audience to consider, for example, the value of learning, and as Lampatho and Quadratus debate the matter, the latter talks of the commonplacing he has been trained to do at school. "[S]even useful springs/ Did I deflower in quotations", he tells the assembled company, but "[t]he more I learnt the more I learnt to doubt" (844-847). Quadratus's response (a growing list of grammar points and classical authors he learnt, each one followed by "still my spaniel slept") ends, of course, with the humorous dog knowing just as much as he does:

I stagger'd, knew not which was firmer part, But thought, quoted, read, observ'd and pried, Stuff'd noting-books; and still my spaniel slept. At length he wak'd and yawn'd, and by yon sky, For aught I know he knew as much as I.

(868-872)

The play's portrayal of the schoolmaster at work with his boys is clearly evocative for many of the men who watch the scene, enjoying the witty young Holofernes Pippo's teasing of his master.

Adding to the play's self-awareness, the contrast between learning and theatre is made apparent in the schoolmaster's comment that, in finding a position with Simplicius (the gentleman who is "enamour'd on [the] boy"), Pippo has been rescued from a career as an actor. His schoolmaster "was solicited to grant him leave to play the lady in comedies presented by children, but I knew his voice was to small and his stature to low" (797-799). This highly metatheatrical play, which refers to its own title laboriously throughout, begins with an introduction to a man supposedly mad for love. Convinced by Jachimo's outpouring of emotion, "unbraced and careless dres'd" (as Ophelia might have noted of the mad Hamlet), Quadratus finally admits "now I see he's mad most palpable, / He speaks like a player" (172-173). The players make continual reference to 
their own costumes and disguises, and to the immaturity of the actors, building a conspiratorial tone embracing those on stage and those in the auditorium.

The play's relationship with women is one that seems designed to appeal to the homosocial Innsmen. There is a pervasive fear of "the female presence", which one of the actors claims "will put [him] out" (106) as the plays starts, and the opening appeal appears to exclude them, being to "the kinde Gentlemen, and most respected Auditors" (114-115). Despite the necessary presence of female love objects for the romantic heroes to fall in love with, there is a pervasive presence of misogyny akin to that of the Prince D'Amour revels. As the men of the Middle Temple a few years earlier had laughed along with the revels court of the Prince of Love (surrounded by specially dubbed Knights of the Quiver as well as the more usual Secretary, Treasurer and so on), the opportunities for double entendre were manifold. The clear purpose was to create collusion between the men in the Hall, and while apparently flattering women, jokes often betray the interests, fears and insecurities of the Innsmen. In the revels, the innuendo is ubiquitous. In outlining the responsibilities of the officers of the Prince, his Lord President, undoubtedly representing the older barristers, is announced as follows: "The President of the Councel is to give order for the Aged, that they may not be long standing; and if they urge any reason unto their Ladies, they follow it not effectually or to the point..." ${ }^{26}$ One can hear the echo of the schoolboy review, with unusual permission to mock their teachers, and to use double entendre in public which is normally sniggered over in private. The revels continue:

\footnotetext{
That proclamation be made, that any Gentlewoman being taken in the Armes of any Gentleman, be presumed to be his Sister, or his Cousin at the least, and that she be presumed to be no better then swowning, and he striving to put life into her [...] [M] ost of their deliberations be about the Seige of sluce, the Battery of Brest, or sacking of Maidenhead.
}

Similar appeal is clearly made to the audience of What You Will, with Quadratus encouraging the young page to sing and dance with the instruction, "Stand stiff, ho, stand, take footing firm, stand sure, / For if thou fall before thy mistress / Thy manhood's damn'd" (656-658). Marston knew the Innsmen segment of his audience well; he was one of them. Both Shakespeare and Marston knew how to write to engage them.

Various suggestions have been made about the relationship between Shakespeare and Marston at the turn of the century. Some, such as Marston editor W. Reavley Gair, suggest that the two were in direct competition. ${ }^{27}$ Modifying this slightly in his later work on Paul's boys, Gair talks of a possible co-operation between Paul's and the Globe against the rising popularity of the Children of the Chapel Royal at Blackfriars, suggesting that Marston and Shakespeare could have joined this project. ${ }^{28}$ Others propose that the two men knew each other well and worked more closely. Katherine Duncan-Jones, for instance, in her biography of Shakespeare suggests "friendly emulation" or even "collusion" in the writing of Hamlet and Antonio's Revenge, and of Twelfth Night and What You Will. ${ }^{29}$ This essay has given examples of the dramatists' playful interrelations in this period, and it is perhaps not necessary to see anything beyond this in the clearly mutually referential work of Marston and Shakespeare. However, the echoing of the titles in these two comedies suggests a more deliberate connecting which appears to override superficial generic differences. Students of Shakespeare used to be trained to consider him less historically specific, beyond the contemporary references of satire: seeing him instead creating universal characters 
with psychological and emotional depth. More recent scholarly approaches encourage us rather to see Shakespeare within his context - working within playing companies and collaborating with other writers rather than as an isolated genius. It now appears perverse to imagine his work ignoring contemporary theatrical disputes or failing to respond to the preferences and interests of influential audience segments.

The metatheatrical induction to What You Will shows a contemporary fear of audience disapproval which matches that of Jonson. The references to "Sir Signior Snuff, Monsieur Mew, and Cavaliero Blirt [...] three of the most to be fear'd auditors" (1. 14-16) do not of course embody particular individuals but the spirit and violence of potential audience disapproval which the play aimed not to incur. The closing verse of Feste's final song similarly shows the playing company's awareness of the need for approval. He assures them "we'll strive to please you every day" (5.1.404), and both Marston and Shakespeare, as playwrights for the public theatre, self-evidently strove to please all those who paid to see their work. Yet it is possible to argue that some segments of that audience expected to be more specifically catered for. Middle Templars packed their own Hall to see Twelfth Night and went to the nearby Paul's playhouse to see and hear plays written by their fellow, John Marston. Along with the men of the other Inns of Court, they were regular playhouse attenders, with their range of shared expectations and experiences, and this essay aims to suggest how influential a segment they were of the early audiences of both playwrights' under consideration here. In this way, the men of the Inns remain a segment whose influence is visible and audible in the plays by Shakespeare and his contemporaries as we experience them today.

\section{NOTES}

1. See, for example, Lucy Munro's arguments that the boys companies' output encouraged the development of tragicomedy on stage. It is worth noting that audiences did not always respond positively to such developments when first seen. Indeed, disapproval of Fletcher's innovative tragicomedy, The Faithful Shepherdess, suggested that such generic developments could require determination on the part of playwrights. See Munro, The Children of the Queen's Revels, Cambridge, Cambridge University Press, 2005, p. 125 and p. 132.

2. George Buc[k], The third universitie of England. Or a treatise of the foundations of all the colledges, auncient schooles of priviledge, and of houses of learning, and liberall arts, within and above the most famous cittie of London, London, Thomas Dawson, 1615.

3. Ben Jonson, opening to the dedicatory epistle to the 1616 folio edition of Every Man Out of his Humour, where he labels the gentlemen of the Inns "judges of these studies". The Dedication is reproduced in full as Appendix C of Helen Ostovitch's Revels edition of the play, Manchester, Manchester University Press, 2001, and this is the edition from which line references are taken throughout this essay.

4. Philip J. Finkelpearl, John Marston of the Middle Temple: An Elizabethan Dramatist in His Social Setting, Cambridge, Mass., Harvard University Press, 1969, p. 11. 
5. See Andrew Gurr, Playgoing in Shakespeare's London, Cambridge, Cambridge University Press, $3^{\text {rd }}$ edition, 2004; Charles Whitney, Early Responses to Renaissance Drama, Cambridge, Cambridge University Press, 2006. The term "segments" is adopted by the latter.

6. Jeremy Lopez, Theatrical Convention and Audience Response in Early Modern Drama, Cambridge, Cambridge University Press, 2003.

7. Hamlet, 2.2.339-344. All quotations from Shakespeare, henceforth embedded in the text, are from The Complete Works, ed. by Stanley Wells, Gary Taylor et al., Oxford, Clarendon Press, 1986.

8. Gurr, op. cit., p. 68. He goes on to argue that although Innsmen were common in both varieties of playhouse during the period under discussion here, "[a]fter about 1610 all the gentry, and especially the Inns of Court students, went almost exclusively to the hall theatres".

9. In her establishment of satiric, pastoral and, subsequently, tragicomic modes in the works presented by the Children of the Queen's Revels, Lucy Munro begins by emphasising that " $[t]$ he vogue for verse satire in the 1590 s was largely a product of the Inns, where writers such as Marston and Donne were resident" and she notes "the students' fondness for satiric writing" (Munro, op. cit., p. 99).

10. William R. Jones, “The Bishops' Ban of 1599 and the Ideology of English Satire”, Literature Compass 7/5 (2010), 332-346.

11. As well as Marston's Pygmalion, with Certain other Satyres (1598) and Scourge of Villainy (1598), Guilpin's Skialetheia (1598), Dymoke's Caltha poetarum, or, The Bumble Bee (1599, written under the pseudonym Thomas Cutwode) and Davies's Epigrams (1599) were named.

12. James P. Bednarz, Shakespeare and the Poets' War, New York, Columbia University Press, 2001, p. 13: "Yet it was in opposition to Shakespeare that [Jonson] designed comical satire to displace romantic comedy".

13. See Marston's The Scourge of Villainy, 9.129-130, in The Poems of John Marston, ed. by Arnold Davenport, Liverpool, Liverpool University Press, 1961, p. 162: “I'le stryp you nak'd, and whyp you with my rimes,/ Causing your shame to liue to after times".

14. John Manningham, Diary of John Manningham of the Middle Temple and of Bradbourne, Kent, Barrister-at-Law, 1602-3, ed. by John Bruce, Esq., London, J. B. Nichols and Sons, 1868, p. 18.

15. Benjamin Rudyerd, Le Prince D'Amour, London, William Leake, 1660, p. 82.

16. For further discussion of the Inns as training grounds for aspirant courtiership, exploring the visual appearance and verbal skills they helped men develop, see my article, "He writes, he railes, he jests, he courts, what not, / And all from out his huge long scraped stock/ of well penn'd playes': learning the performance of courtiership at the early modern Inns of Court", Spectatorship at the Elizabethan Court, ed. by Susanne Scholz and Daniel Dornhofer, special issue of Zeitspruenge. Forschungen zur Fruehen Neuzeit 17 (2013), 63-83.

17. As Frank Whigham, in his study of courtesy literature, explains, such books are interesting because they explain from within how social mobility is to be achieved. What had originated as exclusive was appropriated by those wishing to appear a true aristocrat: "Movement across the gap between ruling and subject classes was becoming increasingly possible, and elite identity had begun to be a function of actions rather than of birth - to be achieved rather than ascribed" (Whigham, Ambition and Privilege: The Social Tropes of Elizabethan Courtesy Theory, Berkeley, University of California Press, 1984, p. 5).

18. Giovanni Della Casa, Galateo, London, Raufe Newbery, 1576, p. 108-109. That the first English translation of this text was by Robert Peterson of Lincoln's Inn suggests the interest of Innsmen in such texts. This is also demonstrated in Middle Templar Bartholomew Yong's translation of Book 4 of one of the other key courtesy books of the period, Guazzo's Civile Conversation, London, Thomas East, 1586.

19. The relationship between late Elizabethan sumptuary laws and the Inns is an interesting one. Although Elizabethan legal restrictions on the dress of each societal level were clear before they were repealed by Parliament in 1604, they can be argued to have been more honoured in the 
breech than the observance. See Robert I. Lublin, Costuming the Shakespearean Stage, Farnham, Ashgate, 2011, p. 45. This is perhaps particularly the case at the Inns of Court, where records of the Inns' parliaments show regular reprimands for young men breaking dress codes. By the late Elizabethan period, though - at Middle Temple - these sartorial reprimands are more usually for wearing inappropriate clothing (hats or boots) in hall or in chapel. See Charles Henry Hopwood, ed., Middle Temple Records, London, 1904, Vol. I, p. 359 and 413.

20. See introduction to Twelfth Night, ed. John Dover Wilson, Cambridge, Cambridge University Press, 1930, and Anthony Arlidge, The Prince of Love, London, Giles de la Mare, 2000.

21. Henk K. Gras, "Twelfth Night, Every Man Out of his Humour, and the Middle Temple Revels of 1597-98”, Modern Language Review, 84 (1989), 545-564; p. 546.

22. Philip J. Finkelpearl, op. cit., p.164.

23. See, for example, Kier Elam in the introduction to his recent Arden 3 edition, London, Arden Shakespeare, 2008.

24. John Marston, What You Will, Nottingham Drama Texts edition, ed. by M. R. Woodhead, Nottingham, Nottingham University Press, 1980, 1. 243. References are henceforth in the text.

25. For possible echoes of Hamlet, see for example, lines 339 ("god night sweete wench"), 397 ("You haue our brothers picture"), and 1017 ("woman is the weaker creature" and several references to a woman's reaction to a suggested second marriage). A quotation from Richard III comes, for example, at 523 ("A horse, a horse, my kingdom for a horse").

26. Rudyerd, op. cit., p. 22-23.

27. In the Introduction to Gair's Revels edition of Antonio's Revenge, Manchester, Manchester University Press, 1978, p. 13.

28. W. Reavley Gair, The Children of Paul's; the story of a theatre company, 1553-1608, Cambridge, Cambridge University Press, 1982, pp. 133-134.

29. Katherine Duncan-Jones, Ungentle Shakespeare: Scenes from his Life, London, Arden Shakespeare, 2000, p. 136.

\section{ABSTRACTS}

This article considers the relationship between two plays and their late 1590s audiences. After establishing the influence of the men of the Inns of Court as an audience "segment" in this period, it argues that both Shakespeare's Twelfth Night and Marston's What You Will respond to some of the shared experiences and interests of this group. Both plays were performed during the Poetomachia, the stage aftermath of the 1599 Bishops' Ban on Juvenalian satire, and the Innsmen's famous connection with the satiric genre is influential on playhouse production at the end of Elizabeth's reign. After Jonson's Every Man Out of his Humour (for which he adopted the epithet "satirical comedy") the plays of the War of the Theatres engaged in the fashion for satire, but I argue that both Marston and Shakespeare responded in more than simply generic terms to wider issues which engaged an audience segment of Innsmen. Thus in their focus on an aspirant man's appearance, on the connection between performance on and off stage, on the role of education and on the place of women, both Twelfth Night and What You Will show the importance of this segment to the late Elizabethan playhouse repertoire.

Cet article envisage le rapport entre le public élisabéthain et deux pièces de la fin des années 1590, La Nuit des Rois de Shakespeare et What You Will de Marston. Une fois établie l'influence des 
hommes des Inns of Court en tant que « segment » de public à cette époque, l'argument avancé est que ces deux pièces répondent à des expériences et des intérêts communs aux membres de ce groupe. Toutes deux jouées durant la «Poétomachie», qui porta sur les scènes de théâtre la satire juvénalienne après le décret de 1599 la frappant d'interdit dans les textes imprimés («Bishops' Ban»), elles témoignent de l'influence du genre satirique associé aux membres des Inns sur la production dramatique de la fin du règne d'Élisabeth. Si, à la suite d'Everyman Out of His Humour de Jonson (que l'auteur qualifiait de «comédie satirique »), les pièces de la Guerre des Théâtres adoptèrent la mode de la satire, Marston et Shakespeare semblent réagir au-delà des enjeux génériques à des questions plus larges qui concernent le segment du public représenté par les membres des Inns. En mettant l'accent sur l'apparence de personnages rêvant d'ascension sociale, sur le lien entre le spectacle sur scène et hors scène, sur le rôle de l'éducation et sur la place des femmes, La Nuit des Rois et What You Will montrent l'importance de ce «segment » dans l'élaboration du répertoire dramatique élisabéthain.

\section{INDEX}

Keywords: audience, Inns of Court, Marston John, Poetomachia, satire, Twelfth Night, What You Will

Mots-clés: Inns of Court, Marston John, Nuit des Rois (La), Poétomachie, public, satire, What You Will

\section{AUTHOR}

JACKIE WATSON

Independent scholar 